\title{
DNA risks: fears calmed, but doubts remain
}

EXPERIMENTS carried out by research workers at the US National Institutes of Health have provided little evidence to support fears that bacteria carrying recombinant plasmids or phages containing a eukaryotic viral genome could themselves become producers of virus particles.

However, the research workers have shown that free viral DNA is capable of producing infection in mice when injected under the skin, and that infection can also be caused by recombinant phages in which the viral DNA occurs twice in succession. They have also raised the possibility, now receiving further study, that the recombinant molecules could present a hazard by transforming cells into a tumorgenic state.

These results have emerged from a series of experiments carried out at the top-level containment facilities of Fort Detrick in Maryland as part of a programme to assess the potential risks posed by the use of recombinant DNA techniques.

A team of research workers from the National Institute of Allergy and Infectious Diseases at NIH, headed by Dr Wallace P. Rowe and Dr Malcolm A. Martin, conducted two series of experiments. One involved the molecular cloning of polyoma virus in a disabled $E$. coli plasmid vector system, and the other involved studying recombinants formed between a lambda phage vector and polyoma DNA.

In the first series of experiments, the research workers found that although all the recombinants studies contained the complete, potentially infectious viral DNA, in no case did either the recombinant plasmid, or live $E$. coli containing the plasmid, cause polyoma infection in mice.

In the second series, two types of recombinant phage were found to have formed, the most common containing a single copy of the polyoma DNA, but a second type containing two copies of the DNA linked head-to-tail in tandem. The phages containing the single copies was not infectious in mice, either when given directly, or when used to infect concentrated suspensions of $E$. coli from which the DNA was extracted and administered to the mice.

However, the phages containing the tandem inserts - theoretically more likely to cause infection since polyoma genomes could be generated by intramolecular recombination-did indeed prove to be infectious in two of five

mice inoculated with the phage DNA, and in two of five injected with DNA prepared from $E$. coli infected with the phage.

According to the research workers, whose findings are about to be published in Science, the latter result indicates that the possible cloning of head-to-tail inserts should be taken into consideration in carrying out risk assessment analysis of the cloning of DNA, although they say that such an occurrence is highly unlikely to occur, particularly in shot-gun experiments.

The research workers say that similar results on the low infectivity of cloned genomes can be predicted for other members of the Papovaviridae family of viruses-including the SV40 virus-as well as most other DNA viruses, containing larger and more complex genes.

However, they draw attention to a potential hazard that might be caused by the ability of bacteria containing virus DNA recombinants to induce tumours. This hypothesis is based on the ability of polyoma DNA to induce tumours in young hamsters by transforming cells; tests of any potential hazard are now being investigated.

David Dickson

\section{Science gets new champion on Capitol Hill}

IT IS unusual to find a US Congressman demanding a strong, centralised state planning mechanism, a device usually associated with the nation's ideological rivals. Just such a mechanism, however, is being proposed by a member of the House of Representatives whose voice on science policy matters will be frequently heard over the next two years: Representative George Brown of California.

First elected to Congress in 1953, $\mathrm{Mr}$ Brown has been chosen to chair the science, research and technology subcommittee of the House science and technology committee. The subcommittee's responsibilities will be expanded by incorporating the domestic and international scientific planning committee; and the result will be to make it broadly responsible for overseeing the nation's research efforts and science policy.

$\mathrm{Mr}$ Brown is unashamedly partisan. "Some people talk of science as the handmaiden of society; I want to see science as a leader in our national culture", he said in an interview with Nature last week.

$\mathrm{He}$ is critical of a "laissez faire" attitude to research and development. where national concerns merely adjust the broad parameters of programmes rather than their more precise $\mathrm{dy}$ namics. The US, he says, lacks "a coordinated national approach to giving both direction and resources to the scientific community".

With the general pressure on research budgets, funding innovations must concentrate on the reorganisation, rather than the expansion, of resources, he says.

If this sounds a bit vague, then $\mathrm{Mr}$ Brown can point to his recent experience in helping steer through Congress legislation to set up co-ordinated programmes of climate and earthquake research-efforts which have earned him widespread respect in the scientific community-as well as his involvement in agricultural and environmental research issues.

But not all agree with the primacy that he would allot to science. During last year's debate on the climate programme, for example. the OSTP successfully headed off an effort to make it lead agency for the programme, a task nassed to the Department of Commerce's National Oceanographic and Atmosnheric Administration.

$\mathrm{Mr}$ Brown remains convinced that OSTP should be at the ton of the pile. Although welcoming the increased funds that the science adviser has

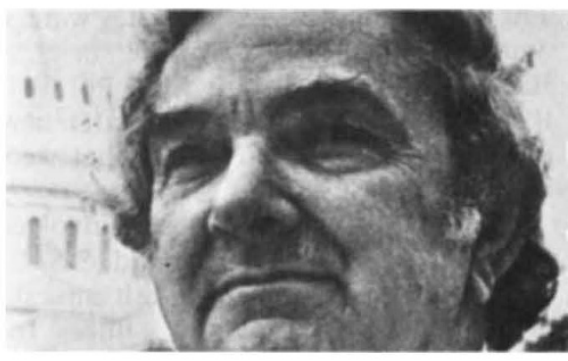

Congressman George Brown: "I want to see science as a leader in our culture."

helped secure for basic science, he claims that OSTP has not confronted to the intentions and the language of the legislation which set it up in 1976.

"We had hoped that the science adviser's office would give some coherence and strategic planning to soience, and it has not done so, leaving quite a lot of unfulfilled expectations", he says.

At OSTP they see things slightly differently. "Some of these expectations were perhaps partly misplaced. We are not a kind of national clearing house on R \& D", one official said last week.

Nevertheless mechanisms by which the nation's scientific efforts can be given "improved leadership" are high on $\mathrm{Mr}$ Brown's agenda. "The period of substantial growth experienced by science a decade ago has been extremely valuable: but it is now time to do some stocktaking". David Dickson 